\title{
Ninety-Eighth Annual Report of The American Phytopathological Society
}

\section{REPORT OF THE TREASURER}

The Financial Advisory Committee (FAC) and APS headquarters' staff met on 29 July 2006 in Quebec City, Canada to review financial matters related to the operation of the Society and to refine the strategic financial plan. APS has made considerable progress in renewing the strategic plan, mission and vision for the future. Council and the officers regularly analyze the external environment and make progress toward assigning responsibility for developing and executing strategies to attain the goals of the strategic plan. A long-range financial plan provides APS with the practical considerations to bridge the gap from the current budget to support the goals of the APS strategic plan. Having a strategic financial plan will help us, as a Society, provide a focus for our resources. This process has advantages for guiding the various committees and staff to do their jobs. They will know what is expected from their programs several years in advance so they can build and execute strategies over several budget years. The role of FAC in this process is not to get involved in strategy building, but rather to decide what the financial goals are. What programs do we expect to generate surplus revenues to pay for the services and benefits to our members and those that cannot pay their own way? What programs should break even or lose money? Where should our focus be?
The FY06 budget was concluded with a surplus of $\$ 535,027$, which represents $12 \%$ of our total income for the period. The 11 income and expense categories for the Society are detailed in Table 1. Our total income $(\$ 4,289,254)$ was derived from six sources as indicated in Figure 1, and our total operating expenses $(\$ 3,754,227)$ incurred during FY06 were partitioned as indicated in Figure 2.

The income and expenses of the Society for the most recent FYs are presented in Table 2. The total assets of the Society as of 30 June 2006, including restricted funds, were \$6.9 million and current liabilities totaled $\$ 2.3$ million. This resulted in total net assets of $\$ 4.6$ million.

TABLE 2. Comparison of The American Phytopathological Society fiscal years 1997 to 2006 after reserve allocation

\begin{tabular}{lccc}
\hline Fiscal year & Income & Expenses & Surplus (deficit) \\
\hline FY06 & $\$ 4,289,254$ & $\$ 3,754,227$ & $\$ 535,027$ \\
FY05 & $\$ 3,959,027$ & $\$ 3,819,096$ & $\$ 139,931$ \\
FY04 & $\$ 3,963,006$ & $\$ 3,700,013$ & $\$ 262,993$ \\
FY03 & $\$ 3,748,845$ & $\$ 3,864,217$ & $(\$ 115,372)$ \\
FY02 & $\$ 4,045,587$ & $\$ 3,997,846$ & $\$ 47,741$ \\
FY01 & $\$ 3,952,594$ & $\$ 4,059,101$ & $(\$ 106,507)$ \\
FY00 & $\$ 3,649,863$ & $\$ 3,724,910$ & $(\$ 75,047)$ \\
FY99 & $\$ 3,662,093$ & $\$ 3,692,259$ & $(\$ 30,166)$ \\
FY98 & $\$ 3,589,253$ & $\$ 3,431,727$ & $\$ 157,526$ \\
FY97 & $\$ 3,418,515$ & $\$ 3,216,088$ & $\$ 202,427$ \\
\hline
\end{tabular}

TABLE 1. Audited summary of income and expenses as related to function of The American Phytopathological Society

\begin{tabular}{|c|c|c|c|c|c|c|c|c|c|}
\hline \multirow[b]{2}{*}{ Function } & \multicolumn{4}{|c|}{ Income } & \multicolumn{4}{|c|}{ Expenses } & \multirow[b]{2}{*}{ Profit (loss) } \\
\hline & Actual & $\%$ & Budget & $\%$ & Actual & $\%$ & Budget & $\%$ & \\
\hline Member Services & 326,993 & $8 \%$ & 314,600 & $7 \%$ & 667,671 & $18 \%$ & 724,705 & $16 \%$ & $(340,678)$ \\
\hline Short Courses & 108,325 & $3 \%$ & 71,350 & $2 \%$ & 76,516 & $2 \%$ & 57,903 & $1 \%$ & 31,809 \\
\hline Phytopathology & 829,649 & $19 \%$ & 868,600 & $20 \%$ & 296,764 & $8 \%$ & 352,779 & $8 \%$ & 532,885 \\
\hline Plant Disease & 763,460 & $18 \%$ & 770,100 & $18 \%$ & 328,322 & $9 \%$ & 363,081 & $8 \%$ & 435,138 \\
\hline Phyto News & 9,579 & $0 \%$ & 8,265 & $0 \%$ & 55,222 & $1 \%$ & 61,366 & $1 \%$ & $(45,643)$ \\
\hline MPMI & 574,438 & $13 \%$ & 544,400 & $12 \%$ & 296,124 & $8 \%$ & 327,901 & $7 \%$ & 278,314 \\
\hline Plant Management Network & 204,097 & $5 \%$ & 294,912 & $7 \%$ & 250,450 & $7 \%$ & 296,029 & $7 \%$ & $(46,353)$ \\
\hline Online Subscriptions & 39,556 & $1 \%$ & 29,100 & $1 \%$ & 18,314 & $0 \%$ & 33,826 & $1 \%$ & 21,242 \\
\hline APS Press & 853,520 & $20 \%$ & 805,654 & $18 \%$ & 660,006 & $18 \%$ & 648,566 & $15 \%$ & 193,514 \\
\hline Annual Meeting & 532,812 & $12 \%$ & 651,725 & $15 \%$ & 356,349 & $9 \%$ & 530,155 & $12 \%$ & 176,463 \\
\hline $\mathrm{G} \& \mathrm{~A}^{\mathrm{a}}$ & 46,825 & $1 \%$ & 7,250 & $0 \%$ & 748,489 & $20 \%$ & $1,001,355$ & $23 \%$ & $(701,664)$ \\
\hline Total & $4,289,254$ & $100 \%$ & $4,365,956$ & $100 \%$ & $3,754,227$ & $100 \%$ & $4,397,666$ & $100 \%$ & 535,027 \\
\hline Surplus (loss) & & & & & & & & & 535,027 \\
\hline
\end{tabular}

${ }^{\mathrm{a}} \mathrm{G} \& \mathrm{~A}$ is assigned to functions based on payroll dollars.

Income

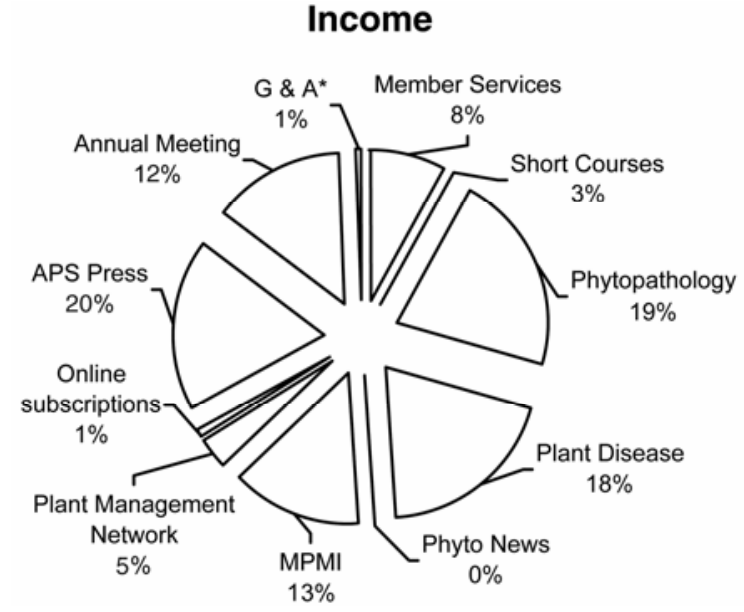

Fig. 1.

DOI: 10.1094/PHYTO-97-0017
Expenses

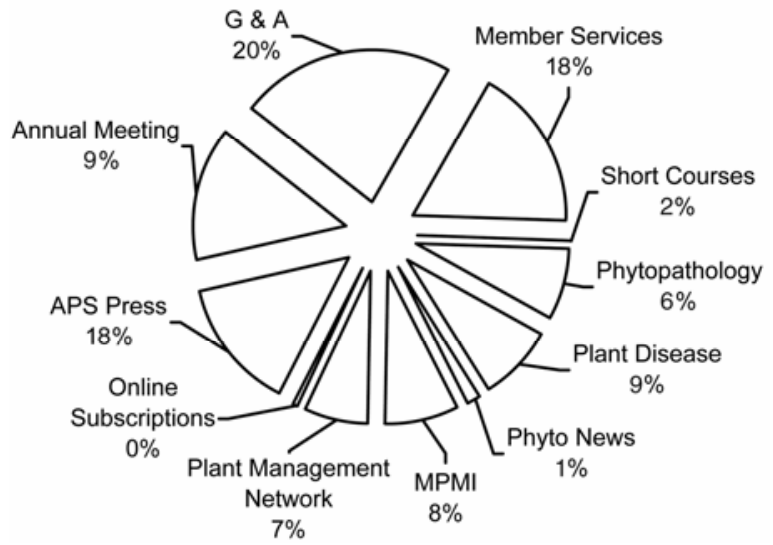

Fig. 2. 
The FY06 net income was unusually high due to several factors that were unexpectedly positive this year. This extra income will be re-invested into APS. For example, with a portion of the FY06 surplus, the Board chose to buy down the hotel rates for the Quebec City meeting so that it would be less expensive for members to attend. Other initiatives continue to enhance member services including our Washington, DC presence (Eversole Associates) and the increased activity of the Public Policy Board, the increased use of reserves of the Society in supporting programming at the APS Annual Meeting, and investing in the Plant Management Network. The future of the Plant Management Network looks much more promising with increased content (including for peer reviewed journals), partners, and subscribers, and our increased presence in Washington has brought benefit to our discipline and membership. Although still a net loss this fiscal year, the financial future of PMN is improving each year. The Treasurer can be contacted at Rowe.4@OSU.edu.

\section{REPORT OF THE AUDITOR}

The American Phytopathological Society has its accounts audited annually by a certified public accountant. In recent years, the accounting firm has been Lethert, Skwira, Schultz, \& Co., St. Paul, MN. Only the Balance Sheet and the Statement of Changes in Net Assets, as of 30 June 2006, are being published in detail. Any member wishing a copy of the full audit may obtain one on request.

The American Phytopathological Society Balance Sheet Year ended 30 June 2006 (with comparative totals for 2005)

\begin{tabular}{|c|c|c|}
\hline & 2005 & 2006 \\
\hline \multicolumn{3}{|l|}{ Assets } \\
\hline Cash (note 3) & $2,539,945$ & $1,008,526$ \\
\hline Accounts receivable, net (notes 2 and 16) & 300,624 & 479,109 \\
\hline Unconditional promises to give & 7,850 & 69,879 \\
\hline Investments (note 4) & $1,818,920$ & $4,067,542$ \\
\hline Prepaid expense (note 5) & 270,173 & 442,036 \\
\hline Inventory & 665,696 & 619,517 \\
\hline Prepaid pension (note 13) & 33,345 & 47,617 \\
\hline Property and equipment, net (notes 6,8 , and 17 ) & 355,998 & 360,631 \\
\hline Total assets & $5,992,551$ & $7,094,857$ \\
\hline \multicolumn{3}{|l|}{ Liabilities and net assets } \\
\hline Accounts payable (note 16 ) & 247,048 & 253,465 \\
\hline Accrued payroll and payroll taxes & 30,883 & 40,757 \\
\hline Accrued pension expense & 82,544 & 81,844 \\
\hline Agency funds payable & 12,453 & 13,442 \\
\hline Deferred revenues (note 7) & $1,613,490$ & $1,847,490$ \\
\hline Long-term debt (notes 8 and 17) & 781 & - \\
\hline Total liabilities & $1,986,762$ & $2,236,998$ \\
\hline \multicolumn{3}{|l|}{ Net assets } \\
\hline Unrestricted (note 9) & $2,846,750$ & $3,495,852$ \\
\hline Temporarily restricted (note 10 ) & 149,898 & 321,301 \\
\hline Permanently restricted (note 11 ) & $1,009,141$ & $1,040,706$ \\
\hline Total net assets & $4,005,789$ & $4,857,859$ \\
\hline Total liabilities and net assets & $\$ 5,992,551$ & $7,094,857$ \\
\hline
\end{tabular}

The American Phytopathological Society Statement of Changes in Net Assets Year ended 30 June 2006 (with comparative totals for 2005)

\begin{tabular}{|c|c|c|}
\hline & 2005 & 2006 \\
\hline \multicolumn{3}{|l|}{ Unrestricted net assets (support and revenue) } \\
\hline Federal financial assistance & 49,000 & 44,051 \\
\hline Contributions & 4,346 & 75,950 \\
\hline Membership dues & 286,628 & 282,910 \\
\hline Subscriptions & $1,775,368$ & $1,847,556$ \\
\hline Reprints and demand articles & 74,492 & 67,144 \\
\hline Abstracts & 9,470 & 8,575 \\
\hline Page charges & 208,470 & 219,014 \\
\hline Processing fee & 102,902 & 116,210 \\
\hline Back issues & 7,898 & 8,278 \\
\hline Color charges & 127,284 & 118,803 \\
\hline Advertising & 39,914 & 47,417 \\
\hline Books, slides, and CD-Rom & 704,192 & 838,016 \\
\hline Annual meeting & 560,629 & 533,267 \\
\hline Short courses & - & 39,825 \\
\hline Royalty income & 21,755 & 27,491 \\
\hline Investment income (note 4) & 59,224 & 87,937 \\
\hline Gain (loss) on sale of investments (note 4) & 18,514 & 189,491 \\
\hline Unrealized gain (loss) on investments (note 4 ) & 47,629 & $(112,682)$ \\
\hline Loss on disposal of property & $(3,384)$ & \\
\hline Other & 17,734 & 20,974 \\
\hline Total revenue & $4,112,065$ & $4,460,227$ \\
\hline \multicolumn{3}{|l|}{ Net assets released from restrictions } \\
\hline Restrictions satisfied by payments & 68,721 & 65,799 \\
\hline \multicolumn{3}{|l|}{ Expenses } \\
\hline \multicolumn{3}{|l|}{ Program services } \\
\hline Member services & 668,245 & 688,594 \\
\hline Journals & $1,199,402$ & $1,226,883$ \\
\hline Books & 547,465 & 670,698 \\
\hline Annual meeting & 602,151 & 413,024 \\
\hline Grants and awards & 30,781 & 29,970 \\
\hline Short courses & 43,039 & 98,002 \\
\hline Online services & 16,531 & 18,314 \\
\hline Total program services & $3,107,614$ & $3,145,485$ \\
\hline \multicolumn{3}{|l|}{ Supporting services } \\
\hline Management and general & 854,760 & 730,688 \\
\hline Fundraising & 2,043 & 751 \\
\hline Total supporting services & 856,803 & 731,439 \\
\hline Total expenses & $3,964,417$ & $3,876,924$ \\
\hline Increase in unrestricted net assets & 216,369 & 649,102 \\
\hline \multicolumn{3}{|l|}{ Temporarily restricted net assets } \\
\hline Support for books & 25,530 & 30,119 \\
\hline Support for annual meeting socials & 19,028 & 145,689 \\
\hline Support for student travel & 4,718 & 5,216 \\
\hline Investment income (note 4 ) & 18,145 & 22,572 \\
\hline Loss on sale of investments (note 4) & 7,027 & 77,198 \\
\hline Unrealized gain (loss) on investments (note 4 ) & 3,104 & $(43,592)$ \\
\hline Restrictions satisfied by payments & $(68,721)$ & $(65,799)$ \\
\hline Increase (decrease) in temporarily restricted net assets & 8,831 & 171,403 \\
\hline \multicolumn{3}{|l|}{ Permanently restricted net assets } \\
\hline Support for operations & 10,531 & 4,730 \\
\hline Support for student travel & 78,291 & 25,698 \\
\hline Support for student speakers & 70 & 235 \\
\hline Support for research and education & 1,600 & 1,243 \\
\hline Support for international travel & 7,227 & 480 \\
\hline Unrealized gain (loss) on investments (note 4) & 460 & $(821)$ \\
\hline Increase in permanently restricted net assets & 98,179 & 31,565 \\
\hline Increase in net assets & 323,379 & 852,070 \\
\hline Net assets, beginning of year & $3,682,410$ & $4,005,789$ \\
\hline Net assets, end of year & $4,005,789$ & $4,857,859$ \\
\hline
\end{tabular}

